Article

\title{
Postharvest Treatment of Tribolium confusum Jacquelin du Val Adults with Commercial Biopesticides
}

\author{
Spiridon Mantzoukas ${ }^{1,2, *}$, Ioannis Lagogiannis ${ }^{3}$, Ioannis Pettas ${ }^{4}$, Georgia Korbou ${ }^{2}$, \\ Alexandra Magita ${ }^{2}$, Athanasia Papadopoulou ${ }^{2}$, Maria Trianti ${ }^{2}$, Panagiotis A. Eliopoulos ${ }^{5}$ and \\ Eirini Karanastasi ${ }^{2}$ \\ 1 Department of Pharmacy, School of Health Sciences, University of Patras, Patras 26504, Greece \\ 2 Department of Agricultural Technology, Technological Institute of Western Greece, Amaliada 27200, Greece; \\ georgiakorbou@gmail.com (G.K.); alexandramag@hotmail.gr (A.M.); athanasiap610@gmail.com (A.P.); \\ mariatrianty@yahoo.gr (M.T.); ekaran@teimes.gr (E.K.) \\ 3 ELGO-Demeter, Plant Protection Division of Patras, NEO \& L. Amerikis, Patras 26444, Greece; \\ lagoipp@gmail.com \\ 4 Department of Chemistry, University of Ioannina, Ioannina 45100, Greece; pettasgian@gmail.com \\ 5 Department of Agriculture and Agricultural Technology, University of Thessaly, Larissa 45100, Greece; \\ eliopoulos@uth.gr \\ * Correspondence: mantzoukas@upatras.gr
}

Received: 4 September 2019; Accepted: 17 October 2019; Published: 19 October 2019

check for updates

\begin{abstract}
Within the context of the harmful side-effects of chemical pest control applications, the present study investigated the insecticidal effect of three commercial biopesticides, the fungal Metab (Beauveria bassiana, Metarhizium anisopliae) and Lecan (Lecanicillium lecanii), as well as raw zeolite, against Tribolium confusum Jacquelin du Val (Coleoptera: Tenebrionidae), also known as the confused flour beetle. To this end, we sprayed Tribolium confusum adults with suspensions of the said biopesticides, at three different dosages (250 ppm, 500 ppm, and 1000 ppm) on Avena sativa L. and Linum usitatissimum L. hull and no hull seeds. The data were analyzed in terms of three- and four-way ANOVA model, and the overall survival was determined while using the Kaplan-Meier method. The mortality of Tribolium confusum adults was recorded and analyzed in correlation with the following parameters: dose, product (seed), days, and treatment as factors. At the end of the experiment, all of the biopesticides were effectively pathogenic, but there was variation in their effectiveness in terms of the T. confusum mortality that they caused, depending on the product (seed). The type of seed can play a role in the pathogenicity or effectiveness of the biopesticides. Additionally, our results showed that the mortality percentage was dependent on the dose and treatment of the commercial biopesticides.
\end{abstract}

Keywords: Tribolium confusum; Avena sativa; Linum usitatissimum; Metab; Lecan; zeolite; mortality

\section{Introduction}

Oat (Avena sativa L.) and flax (Linum usitatissimum L.) are two of the most important crops in temperate areas and, economically, they are ranked as two of the eight most important crops in the world [1,2]. Oat seed use for human consumption has progressively increased, thanks to its dietary benefits [2]. Moreover, flax seed is used for oil production as well as in food industries due to its nutritional merits, essential Polyunsaturated fatty acids, and rich supply of soluble dietary fiber [1]. The seed weight of both species is negatively influenced by stored pest infestation.

Insects are major pests of stored products. Stored-product insects are responsible for affecting the quality, quantity, and commercial value of dried stored agricultural commodities, accounting for 
significant post-harvest losses that range from $9 \%$ in developed countries to up to $20 \%$ in developing countries [3]. Coleopterans are among the most common storage pests. Tribolium confusum Jacquelin $\mathrm{du}$ Val (Coleoptera: Tenebrionidae), also known as the confused flour beetle, is a cosmopolitan polyphagous species whose adults and larvae are responsible for severe economic damage in stored products, feeding on several dried foods, including flours, chocolate, fruits, and grains. Infestation results in reduced weight and quality of the product and marketability difficulties. Tribolium spp. also produces carcinogens, the quinones, which can cause allergies and dermatitis, among other disorders [4]. Although T. confusum cannot penetrate intact kernels, it might cause significant damage when the kernel is damp or broken [4]. The control of stored product pests is usually carried out with the application of chemicals to prevent post-harvest losses. However, chemicals are responsible for various problems, including environmental pollution, toxicity to humans and animals, as well as the development of pest resistance [3]. There is a growing need for the exploration of biological control methods within Integrated Pest Management (IPM), to keep pest populations to safer levels while safeguarding the environment and human health [3].

Various biological control agents, including fungi, bacteria, as well as inert dust, are being considered for supplementing or replacing chemical insecticides, which cause toxicity to non-target organisms. Beauveria bassiana (Balsamo) Vuillemin (Hypocreales: Cordycipitaceae), which has been widely tested, has been proven to be effective against several stored product insect species in both laboratory and field tests [5-15], thus showing promise for commercial use. Metarhizium anisopliae (Metschinkoff) Sorokin (Hypocreales: Clavicipitaceae) too, which is a globally distributed mitosporic haploid fungus, is pathogenic to many important agricultural pests [16,17]. All of the above entomopathogenic fungi have proven efficacy against many insect pests of stored grains and grain products. The entomopathogenic fungus Lecanicillium lecanii (Zimmermann) Zare \& W. Gams [previously known as Cephalosporium lecanii] (Hypocreales: Cordycipitaceae) [18,19], is capable of infecting various insect pests, has a broad geographical distribution, and, therefore, also appears to be promising for commercial development.

Another potential biological agent is zeolite, which has been relatively less studied for its control against stored product pests. Zeolite has been investigated for its potential insecticidal effect against Sitophilus oryzae L. (Coleoptera: Curculionidae) and Tribolium castaneum Herbst (Coleoptera: Tenebrionidae) adults (also known as the rice weevil and the red flour beetle, respectively) [20]. Zeolite is a crystalline hydrated aluminosilicate of alkali or alkaline earth metals. Natural zeolite forms following the reaction of ash layers and volcanic rocks with alkaline groundwater [21,22].

This is the first paper evaluating the potential of this commercial biopesticides for the control of stored product pests. The objective of the present study was to investigate the insecticidal effect of three commercial biopesticides against adults of the confused flour beetle, Tribolium confusum Jacquelin du Val (Coleoptera: Tenebrionidae), on the hull and no hull seeds of A. sativa and L. usitatissimum, as well as the extent to which the presence of a hull, or lack thereof, in the seeds affects the insecticidal effect of these products.

\section{Materials and Methods}

\subsection{Insects}

The initial batch of T. confusum, counting 1000 individuals, was obtained from infested wheat in the prefecture of Achaia, Greece. Insects were mass produced in an environmentally controlled chamber $\left(25 \pm 1{ }^{\circ} \mathrm{C}, 65 \pm 5 \%\right.$ Relative Humidity, Light:Night 12:12) (PHC Europe B.V/Sanyo/Panasonic Biomedical MLR-352-PE), where they were maintained in $0.25 \mathrm{~L}$ glass jars with $200 \mathrm{~g}$ of sterilized and pesticide-free corn flour. The jars were covered with a sterilized muslin cloth. After two weeks, the original adults were removed by sieving. Each jar was then observed daily to collect the progeny that were placed in separate jars, in accordance with their age. 


\subsection{Biopesticides}

Metab is a commercial biopesticide from the companies Microspore Hellas and Sacom Hellas, (Athens, Greece), which contains B. bassiana and M. anisopliae at concentrations of $11.5 \times 10^{7}$ conidia/mL and $6.5 \times 10^{7}$ conidia/mL respectively. Lecan is a commercial biopesticide, also from the same companies, which contains L. lecanii at $4.22 \times 10^{7}$ conidia $/ \mathrm{mL}$. The above commercial biopesticides are registered for pest biocontrol in Europe, but they have not been tested against T. confusum.

A commercial zeolite formulation was also used in the bioassays (bulk/raw zeolite). The bulk zeolite that is meant for soil amendment was diluted in an aqueous solution with $\mathrm{ddH}_{2} \mathrm{O}$. The above-mentioned process was completed inside a laminar flow chamber (Equip Vertical Air Laminar Flow Cabinet Clean Bench, Mechanical Application LTD, Athens, Greece).

\subsection{Experimental Protocol}

Laboratory-reared mixed sex adult insects $\left(25 \pm 1{ }^{\circ} \mathrm{C}, 65 \pm 5 \%\right.$ R.H., L:N 12:12) (PHC Europe/Sanyo/Panasonic Biomedical MLR-352-PE) $(<1$ week old) were used for this study. Each batch of adults was collected from rearing jars and then placed in 9-cm diameter Petri dishes with $10 \mathrm{~g}$ of sterilized product, after they had been starved for $1 \mathrm{~h}$. To test its pathogenicity against $T$. confusum, each biopesticide was directly sprayed on the adults and the product in the same petri dish, at three different doses, 250 ppm, 500 ppm, and 1000 ppm, with a $2.5 \mathrm{~mL}$ aqueous suspension, while using a Potter spray tower (Burkard Manufacturing Co. Ltd., Rickmansworth, Hertfordshire, U.K.) at $1 \mathrm{kgf} \mathrm{cm}^{-2}$. The products were hull and no hull seeds of $A$. sativa and L. usitatissimum. One hundred T. confusum adults were used for each dose (10 adults in 10 replications) and the experiment was replicated twenty times. The control involved adults and product that had been merely treated with $\mathrm{ddH}_{2} \mathrm{O}$. Petri dishes were observed after $7,14,21$, and 28 days after the spraying.

\subsection{Fungal Identification Method}

The Petri dishes were observed at 7, 14, 21, and 28 days for dead individuals that were collected while using sterilized forceps. The collected dead individuals were immediately submerged in $95 \%$ ethanol for $1 \mathrm{~min}$., washed in sterile distilled water for $5 \mathrm{~min}$., allowed to dry, and then placed on moistened filter paper. Cadavers were kept at $25^{\circ} \mathrm{C}$ for $5-7$ days in the dark, and those that showed signs of fungal infection were noted as infected. These infected individuals were transferred to a Petri dish containing a piece of moistened cotton to promote the outgrowth and sporulation of the respective fungi. External mycelial growth on cadavers was identified while using a stereomicroscope ZEISS Stemi 508 (Carl Zeiss Microscopy GmbH, Jena, Germany) at $2 \times$ magnification, and conidia that were retrieved from the cadavers were recognized using a microscope ZEISS Primo Star (Carl Zeiss Microscopy GmbH, Jena, Germany) at 400× magnification. The median sporulation time was determined for fungal biopesticides.

\subsection{Statistical Analysis}

The corrected percent mortality was calculated while using Abbott's formula [23] and, prior to analysis, these values were arcsine transformed to stabilize variance. Data were then analyzed by means of univariate ANOVA involving a multi-factor analysis, using the general linear model of the SPSS ver. 23 (IBM Corp. 2015, Armonk, NY, USA) [24]. In the case of significant $F$ values, means were compared while using the Bonferroni test. Median lethal time of T. confusum adults and LC50 were calculated by probit analysis with $95 \%$ confidence interval (CI). The Cox Regression method [25] was selected to determine the hazard effect of the factors over T. confusum adults. It is a survival analysis regression model that describes the relation between the event incidence and a set of covariates. Comparison of survival distributions was obtained while using the Breslow test (Generalized Wilcoxon) (SPSS ver. 23). The percentages of sporulating cadavers and the median sporulation time were compared between isolates using the T-Test of the SPSS. A comparison of median lethal time was performed using one-way ANOVA (Biopesticide as a factor). 


\section{Results}

\subsection{Mortality Effect of Commercial Biopesticides against Adults of T. confusum}

The mortality percentage depended on the treatment, dose of the commercial biopesticides, and the product. The final mortality percentages of T. confusum adults, on day 28 after exposure, were 17 to $30 \%$ in the treatments with zeolite, 27 to $50 \%$ in the treatments with Metab, and 23 to $77 \%$ in the treatments with Lecan, on hull L. usitatissimum seeds; 97 to $100 \%$ in the treatments with zeolite, 13 to $47 \%$ in the treatments with Metab, and 17 to $50 \%$ in the treatments with Lecan, on no hull L. usitatissimum seeds (Tables 1 and 2). The final mortality percentages of T. confusum adults were 30 to $53 \%$ in the treatments with zeolite, 13 to $40 \%$ in the treatments with Metab, and 13 to $50 \%$ in the treatments with Lecan, on hull $A$. sativa seeds; 70 to $100 \%$ in the treatments with zeolite, 33 to $50 \%$ in the treatments with Metab, and 37 to $67 \%$ in the treatments with Lecan, on no hull $A$. sativa seeds (Tables 3 and 4). For control adults who had only been treated with $\mathrm{ddH}_{2} \mathrm{O}$, mortality was $3 \%$ on no hull $A$. sativa seeds, $2 \%$ on hull $A$. sativa seeds, $4 \%$ on hull $L$. usitatissimum seeds, and $2 \%$ on no hull L. usitatissimum seeds, at the end of the experiment (Tables 1-4).

Table 1. Mean mortality $(\% \pm \mathrm{SD})$ and median lethal concentration $\left(\mathrm{LC}_{50}\right.$ with Slope $(\mathrm{Sl})$ and Intercept (Int) values) of T. confusum adults, exposed for 28 days to no hull L. usitatissimum seeds that had been treated with Metab, Lecan and Zeolite, at three dose rates. Mean \pm SD values with the same letter within a column are not significantly different $(p<0.05)(F=1.068, \mathrm{df}=6.96, p<0.001)$.

\begin{tabular}{|c|c|c|c|c|c|c|c|}
\hline \multirow{3}{*}{ Product (Seeds) } & \multirow{3}{*}{ Biopesticide } & \multirow{3}{*}{$\begin{array}{l}\text { Dose } \\
(\mathrm{ppm})\end{array}$} & \multicolumn{4}{|c|}{ Mortality $(\% \pm$ SD) } & \multirow{3}{*}{$\mathrm{LC}_{50}$} \\
\hline & & & \multicolumn{4}{|c|}{ Days } & \\
\hline & & & 7 & 14 & 21 & 28 & \\
\hline \multirow{10}{*}{$\begin{array}{c}\text { no hull } \\
\text { L. usitatissimum }\end{array}$} & \multirow{3}{*}{ Metab } & 250 & $7 \pm 6 a$ & $13 \pm 6 a$ & $13 \pm 6 a$ & $13 \pm 6 a$ & \multirow{3}{*}{$\begin{array}{c}3500 \mathrm{ppm} \\
\text { (Sl: } 1.89) \\
\text { (Int: }-6.72)\end{array}$} \\
\hline & & 500 & $7 \pm 6 a$ & $13 \pm 6 a$ & $17 \pm 11 a$ & $17 \pm 11 \mathrm{a}$ & \\
\hline & & 1000 & $7 \pm 11 a$ & $20 \pm 10 a$ & $37 \pm 6 b$ & $47 \pm 15 a$ & \\
\hline & \multirow{3}{*}{ Lecan } & 250 & $7 \pm 6 a$ & $17 \pm 6 a$ & $17 \pm 6 a$ & $17 \pm 6 a$ & \multirow{7}{*}{$\begin{array}{c}1716 \mathrm{ppm} \\
\text { (Sl: } 2.22) \\
\text { (Int: }-7.18) \\
793 \mathrm{ppm} \\
\text { (Sl: } 0.15) \\
\text { (Int: }-0.04)\end{array}$} \\
\hline & & 500 & $7 \pm 11 a$ & $20 \pm 10 a$ & $23 \pm 6 a$ & $27 \pm 6 a$ & \\
\hline & & 1000 & $13 \pm 6 a$ & $20 \pm 10 a$ & $37 \pm 6 b$ & $50 \pm 10 a$ & \\
\hline & \multirow{3}{*}{ Zeolite } & 250 & $20 \pm 0 a$ & $57 \pm 6 b$ & $73 \pm 11 c$ & $97 \pm 0 b$ & \\
\hline & & 500 & $47 \pm 6 a$ & $80 \pm 10 c$ & $93 \pm 6 c$ & $100 \pm 0 b$ & \\
\hline & & 1000 & $83 \pm 12 b$ & $93 \pm 6 c$ & $100 \pm 0 d$ & $100 \pm 0 b$ & \\
\hline & Control & $\mathrm{dd} \mathrm{H}_{2} \mathrm{O}$ & $0 \pm 0 c$ & $0 \pm 0 \mathrm{~d}$ & $2 \pm 0 f$ & $2 \pm 0 c$ & \\
\hline
\end{tabular}

Table 2. Mean mortality ( $\% \pm \mathrm{SD})$ and median lethal concentration $\left(\mathrm{LC}_{50}\right.$ with Slope $(\mathrm{Sl})$ and Intercept (Int) values) of T. confusum adults, exposed for 28 days to hull L. usitatissimum seeds that had been treated with Metab, Lecan and Zeolite, at three dose rates. Mean \pm SD values with the same letter within a column are not significantly different $(p<0.05)(F=1.699, \mathrm{df}=6.96, p=0.035)$.

\begin{tabular}{|c|c|c|c|c|c|c|c|}
\hline \multirow{3}{*}{ Product (Seeds) } & \multirow{3}{*}{ Biopesticide } & \multirow{3}{*}{$\begin{array}{l}\text { Dose } \\
(\mathrm{ppm})\end{array}$} & \multicolumn{4}{|c|}{ Mortality $(\% \pm$ SD) } & \multirow{3}{*}{$\mathrm{LC}_{50}$} \\
\hline & & & \multicolumn{4}{|c|}{ Days } & \\
\hline & & & 7 & 14 & 21 & 28 & \\
\hline \multirow{10}{*}{$\begin{array}{c}\text { hull } \\
\text { L. usitatissimum }\end{array}$} & \multirow{3}{*}{ Metab } & 250 & $13 \pm 15 a$ & $27 \pm 12 a$ & $27 \pm 12 a$ & $27 \pm 12 a$ & \multirow{3}{*}{$\begin{array}{c}4312 \mathrm{ppm} \\
\text { (Sl: } 1.04) \\
(\text { Int: }-3.79)\end{array}$} \\
\hline & & 500 & $23 \pm 15 a$ & $23 \pm 21 a$ & $33 \pm 21 a$ & $40 \pm 16 a$ & \\
\hline & & 1000 & $23 \pm 15 a$ & $40 \pm 10 \mathrm{ab}$ & $50 \pm 17 a$ & $50 \pm 17 a$ & \\
\hline & \multirow{3}{*}{ Lecan } & 250 & $13 \pm 6$ & $17 \pm 6 a$ & $20 \pm 0 \mathrm{a}$ & $23 \pm 6 a$ & \multirow{7}{*}{$\begin{array}{c}1216 \mathrm{ppm} \\
\text { (Sl: } 2.04 \text { ) } \\
\text { (Int: }-6.3 \text { ) } \\
16545 \mathrm{ppm} \\
\text { (Sl: } 0.97) \\
\text { (Int: }-4.11)\end{array}$} \\
\hline & & 500 & $20 \pm 17 a$ & $37 \pm 21 \mathrm{ab}$ & $50 \pm 10 a$ & $50 \pm 10 a$ & \\
\hline & & 1000 & $20 \pm 10 a$ & $57 \pm 6 a b$ & $77 \pm 6 b$ & $77 \pm 6 b$ & \\
\hline & \multirow{3}{*}{ Zeolite } & 250 & $3 \pm 6 a$ & $10 \pm 0 \mathrm{a}$ & $17 \pm 6 a$ & $17 \pm 6 a$ & \\
\hline & & 500 & $7 \pm 6 a$ & $20 \pm 10 a$ & $23 \pm 6 a$ & $23 \pm 6 a$ & \\
\hline & & 1000 & $23 \pm 20 a$ & $27 \pm 21 a$ & $30 \pm 17 a$ & $30 \pm 17 a$ & \\
\hline & Control & $\mathrm{dd} \mathrm{H}_{2} \mathrm{O}$ & $0 \pm 0 \mathrm{~b}$ & $0 \pm 0 c$ & $0 \pm 0 c$ & $4 \pm 0 c$ & \\
\hline
\end{tabular}


Table 3. Mean mortality ( $\% \pm \mathrm{SD}$ ) and median lethal concentration ( $\mathrm{LC}_{50}$ with (Sl) and Intercept (Int) values) of T. confusum adults exposed for 28 days to no hull $A$. sativa seeds that had been treated with Metab, Lecan and Zeolite, at three dose rates. Mean \pm SD values with the letter within a column are not significantly different $(p<0.05)(F=1.586, \mathrm{df}=6.96, p=0.025)$.

\begin{tabular}{|c|c|c|c|c|c|c|c|}
\hline \multirow{3}{*}{$\begin{array}{l}\text { Product } \\
\text { (Seeds) }\end{array}$} & \multirow{3}{*}{ Biopesticide } & \multirow{3}{*}{$\begin{array}{l}\text { Dose } \\
(\mathrm{ppm})\end{array}$} & \multicolumn{4}{|c|}{ Mortality $(\% \pm$ SD) } & \multirow{3}{*}{$\mathrm{LC}_{50}$} \\
\hline & & & \multicolumn{4}{|c|}{ Days } & \\
\hline & & & 7 & 14 & 21 & 28 & \\
\hline \multirow{10}{*}{$\begin{array}{l}\text { no hull } \\
\text { A. sativa }\end{array}$} & \multirow{3}{*}{ Metab } & 250 & $10 \pm 0 \mathrm{a}$ & $20 \pm 10 a$ & $30 \pm 10 a$ & $33 \pm 15 a$ & 7057 ppm \\
\hline & & 500 & $17 \pm 6 b$ & $27 \pm 15 a$ & $33 \pm 6 a$ & $37 \pm 6 a$ & (Sl: 0.31) \\
\hline & & 1000 & $27 \pm 15 b$ & $40 \pm 0 a$ & $40 \pm 0 a$ & $40 \pm 0 a$ & (Int: -1.86$)$ \\
\hline & \multirow{3}{*}{ Lecan } & 250 & $27 \pm 6 b$ & $37 \pm 6 a$ & $37 \pm 6 a$ & $37 \pm 6 a$ & $2855 \mathrm{ppm}$ \\
\hline & & 500 & $27 \pm 6 b$ & $40 \pm 0 a$ & $43 \pm 6 a$ & $43 \pm 6 a$ & (S1: 0.98) \\
\hline & & 1000 & $30 \pm 10 b$ & $47 \pm 12 a$ & $53 \pm 12 a$ & $67 \pm 10 b$ & (Int: -3.45$)$ \\
\hline & \multirow{3}{*}{ Zeolite } & 250 & $3 \pm 6 a$ & $57 \pm 21 a$ & $70 \pm 17 a b$ & $70 \pm 17 b$ & 887 ppm \\
\hline & & 500 & $27 \pm 12 b$ & $63 \pm 6 a$ & $83 \pm 12 a b$ & $93 \pm 6 b$ & (Sl: 0.59) \\
\hline & & 1000 & $47 \pm 6 b$ & $100 \pm 0 b$ & $100 \pm 0 b$ & $100 \pm 0 b$ & (Int: -1.74) \\
\hline & Control & $\mathrm{dd} \mathrm{H}_{2} \mathrm{O}$ & $0 \pm 0 c$ & $1 \pm 0 c$ & $3 \pm 0 c$ & $3 \pm 0 c$ & \\
\hline
\end{tabular}

Table 4. Mean mortality ( $\% \pm \mathrm{SD}$ ) and median lethal concentration ( $\mathrm{LC}_{50}$ with (Sl) and Intercept (Int) values) of $T$. confusum adults exposed for 28 days to hull $A$. sativa seeds that had been treated with Metab, Lecan, and Zeolite, at three dose rates. Mean \pm SD values with the same letter within a column are not significantly different $(p<0.05)(F=.939, \mathrm{df}=6.96, p=0.047)$.

\begin{tabular}{|c|c|c|c|c|c|c|c|}
\hline \multirow{3}{*}{$\begin{array}{l}\text { Product } \\
\text { (Seeds) }\end{array}$} & \multirow{3}{*}{ Biopesticide } & \multirow{3}{*}{$\begin{array}{l}\text { Dose } \\
(\mathrm{ppm})\end{array}$} & \multicolumn{4}{|c|}{ Mortality $(\% \pm$ SD) } & \multirow{3}{*}{$\mathrm{LC}_{50}$} \\
\hline & & & \multicolumn{4}{|c|}{ Days } & \\
\hline & & & 7 & 14 & 21 & 28 & \\
\hline \multirow{10}{*}{$\begin{array}{l}\text { hull } \\
\text { A. sativa }\end{array}$} & \multirow{3}{*}{ Metab } & 250 & $3 \pm 6 a$ & $10 \pm 0 \mathrm{a}$ & $13 \pm 6 a$ & $13 \pm 6 a$ & 2766 ppm \\
\hline & & 500 & $10 \pm 10 a$ & $23 \pm 12 a$ & $27 \pm 6 a$ & $30 \pm 17 a$ & (Sl: 1.86) \\
\hline & & 1000 & $10 \pm 0 a$ & $27 \pm 6 a$ & $40 \pm 10 a$ & $40 \pm 10 a$ & (Int: -6.42$)$ \\
\hline & \multirow{3}{*}{ Lecan } & 250 & $3 \pm 6 a$ & $7 \pm 6 a$ & $13 \pm 6 a$ & $13 \pm 6 a$ & $1748 \mathrm{ppm}$ \\
\hline & & 500 & $7 \pm 12 a$ & $27 \pm 12 \mathrm{a}$ & $30 \pm 6 a$ & $40 \pm 10 \mathrm{a}$ & (Sl: 2.23$)$ \\
\hline & & 1000 & $37 \pm 21 \mathrm{a}$ & $37 \pm 21 a$ & $40 \pm 17 a$ & $50 \pm 20 a$ & (Int: -7.25$)$ \\
\hline & \multirow{3}{*}{ Zeolite } & 250 & $13 \pm 12 a$ & $17 \pm 15 a$ & $30 \pm 10 a$ & $30 \pm 10 a$ & 5475 ppm \\
\hline & & 500 & $17 \pm 15 a$ & $20 \pm 17 a$ & $27 \pm 6 a$ & $33 \pm 6 a$ & (Sl: 0.94$)$ \\
\hline & & 1000 & $20 \pm 10 \mathrm{a}$ & $27 \pm 15 a$ & $33 \pm 12 a$ & $53 \pm 15 a$ & (Int: -3.53) \\
\hline & Control & dd $\mathrm{H}_{2} \mathrm{O}$ & $0 \pm 0 \mathrm{~b}$ & $0 \pm 0 b$ & $1 \pm 0 b$ & $2 \pm 2 b$ & \\
\hline
\end{tabular}

Accordingly, in the case of no hull products, the estimated median lethal concentration (LC50) was lower for zeolite, as compared with Metab and Lecan (Tables 1-4), which indicated higher virulence of zeolite against $T$. confusum. In the case of hull products, the median lethal concentration (LC50) of Lecan was lower when compared to Metab and zeolite (Tables 1-4), indicating a higher virulence of Lecan against $T$. confusum.

Significant differences were recorded between product, biopesticide, doses, and the days of the experiment as factors, in relation to the dependent variable of mortality (Table 1). The effectiveness of the biopesticides was significant against $T$. confusum adults at different doses with different products (Table 5 ). The three-way factor model of product $\times$ days $\times$ dose, product $\times$ biopesticide $\times$ days biopesticide $\times$ dose $\times$ days and the four-way factor model of product $\times$ biopesticide $\times$ doses $\times$ days also showed a significant effect in terms of the mortality of T. confusum adults (Table 5). 
Table 5. ANOVA parameters for mortality levels of T. confusum adults exposed for 28 days to three doses of Metab, Lecan, and Zeolite that had been applied to hull and no hull seeds of $A$. sativa and L. usitatissimum.

\begin{tabular}{lccc}
\hline \multicolumn{1}{c}{ Factor } & Df & $\boldsymbol{F}$ & Sig. \\
\hline Seeds & 3 & 6.643 & .000 \\
Biopesticide & 3 & 85.373 & .000 \\
Dose & 2 & 15.678 & .000 \\
Time & 3 & 49.312 & .000 \\
Seed * Biopesticide & 9 & 9.306 & .000 \\
Seeds * Dose & 6 & .366 & .900 \\
Seeds * Time & 9 & 2.717 & .004 \\
Biopesticide * Dose & 6 & 1.868 & .085 \\
Biopesticide * Time & 9 & 8.733 & .000 \\
Dose* Time & 6 & 1.651 & .132 \\
Seeds * Biopesticide * Dose & 18 & .450 & .976 \\
Seeds * Biopesticide * Time & 27 & 4.759 & .000 \\
Seeds * Dose * Time & 18 & 2.607 & .000 \\
Biopesticide * Dose * Time & 18 & 4.097 & .000 \\
Seeds * Biopesticide * Dose * Time & 54 & 1.956 & .000 \\
Error & 384 & & \\
Total & 576 & & \\
Corrected Total & 575 & & \\
\hline
\end{tabular}

\subsection{Fungal Growth on Cadavers of T. confusum after the Exposure to the Fugnal Biopesticides}

Following treatment with Lecan on no hull A. sativa and L. usitatissimum seeds, we observed a high rate of mycosis on cadavers $(t=12.144, \mathrm{df}=7, p<0.001)$ (Table 6), as well as the shortest sporulation time; four days on no hull $A$. sativa seeds and 4.1 days on no hull L. usitatissimum seeds $(t=16.578$, $\mathrm{df}=7, p<0.001)$ (Table 6).

Table 6. The sporulation percentage and sporulation time on cadavers of T. confusum. Mean \pm SD values with the same letter within a column are not significantly different $(p<0.05)$.

\begin{tabular}{cccc}
\hline Product (Seeds) & $\begin{array}{c}\text { Biopesticide } \\
\text { (Fungal) }\end{array}$ & $\begin{array}{c}\text { Sporulation on } \\
\text { Cadavers (\% + SD) }\end{array}$ & $\begin{array}{c}\text { Sporulation Time on } \\
\text { Cadavers (Days + SD) }\end{array}$ \\
\hline \multirow{2}{*}{ no hull A. sativa } & Metab & $44 \pm 11^{\mathrm{a}}$ & $4.9 \pm 0.2^{\mathrm{a}}$ \\
& Lecan & $58 \pm 8^{\mathrm{a}}$ & $4.0 \pm 0.5^{\mathrm{b}}$ \\
hull A. sativa & Metab & $50 \pm 17^{\mathrm{a}}$ & $5.6 \pm 1.1^{\mathrm{ab}}$ \\
& Lecan & $44 \pm 11^{\mathrm{a}}$ & $5.9 \pm 0.8^{\mathrm{a}}$ \\
no hull L. usitatissimum & Metab & $54 \pm 11^{\mathrm{a}}$ & $5.3 \pm 0.6^{\mathrm{a}}$ \\
& Lecan & $62 \pm 13^{\mathrm{a}}$ & $4.1 \pm 0.5^{\mathrm{b}}$ \\
hull L. usitatissimum & Metab & $57 \pm 10^{\mathrm{a}}$ & $5.7 \pm 0.5^{\mathrm{a}}$ \\
& Lecan & $47 \pm 9^{\mathrm{a}}$ & $5.1 \pm 1^{\mathrm{ab}}$ \\
\hline
\end{tabular}

\subsection{Median Lethal Time of T. confusum Adults after Exposure to the Biopesticides}

The median lethal time of T. confusum adults that were treated with Metab, Lecan, and zeolite were statistically significant in relation to the median lethal time of control adults $(F=3.730, \mathrm{df}=3$, $p<0.001)$. The median lethal time of control adults was very low as compared with the median lethal time of adults that had been sprayed with the biopesticides. More specifically, after the treatment with zeolite, the median lethal time of $T$. confusum adults was $32 \%$ lower than the median lethal time of control individuals ((18.78 days (CI: 17.85-19.70 days)); after the treatment with Lecan, the median lethal time was 15\% lower ((22.82 days (CI: 22.00-23.65 days)), and after the treatment with Metab, it was $17 \%$ lower ((23.45 days (CI: 22.66-24.23 days)). The medial lethal time of control individuals was 27.65 days (CI: 27.42-27.87 days). 


\subsection{Factor Effect on Mortality of T. confusum Adults}

Treatment and Dose are statistically significant with $p$ values of $<0.001$ (Table 7). Treatments and Doses had a major effect on the lethal time of T. confusum adults. The $\operatorname{Exp}(\mathrm{B})$ for Upper limit $95.0 \%$ $\mathrm{CI}$ will be associated with increased hazard as recorded for T. confusum adults on no hull A. sativa and no hull L. usitatissimum seeds. $\operatorname{Exp}(\mathrm{B})$ for Product was 0.962, meaning that product as a factor will be associated with lower hazard, longer survival, and less of an effect on the lethal time of the Coleopteran. The B coefficient for Dose was positive with $\operatorname{Exp}(B)>1$. Higher dose values are associated with greater hazard and therefore shorter survival of $T$. confusum adults. Treatment also displayed positive $B$ coefficient with $\operatorname{Exp}(B)>1$. This showed greater hazard and therefore shorter survival of adults in comparison to the control treatment (Control $\operatorname{Exp}(B)=1)$. Product, on the other hand, had a negative coefficient and $\operatorname{Exp}(B)<1$. This means that some products will be associated with lower hazard and longer survival.

Table 7. Variables in the Equation from Cox regression (Chi-square: $301.764, \mathrm{df}=3, p<0.001$ ).

\begin{tabular}{lrrrrrrr}
\hline & B & Sd & df & Sig. & Exp(B) & \multicolumn{2}{c}{$\mathbf{9 5 . 0 \%}$ CI for $\operatorname{Exp(B)}$} \\
\cline { 5 - 8 } & & & & & & \multicolumn{1}{c}{ Lower } & Upper \\
\hline Treatment & .748 & .049 & 1 & .000 & 1.473 & 1.430 & 1.521 \\
Dose & .308 & .057 & 1 & .000 & 1.360 & 1.216 & 1.521 \\
Product & -.039 & .040 & 1 & .333 & .962 & .889 & 1.041 \\
(Seeds) & & & & & & & \\
\hline
\end{tabular}

\section{Discussion}

The insecticidal efficacy of biopesticides is interlinked with several factors, including insect's behavior and other genetic and physiological information, the extent to which the physiology and morphology of the host render it sensitive to biological control agents, such as biopesticides [26-29], as well as the product. Our results showed that the different efficacy of the tested biopesticides depended on the product, on the dose, on the isolates, and their interaction. Our results indicated that stored product pests can be controlled with biopesticides, especially zeolite (lower LC50 on no hull seeds) and Lecan (L. lecanii) (lower $\mathrm{LC}_{50}$ on hull seeds), which produced good results. Several published studies are available on the efficacy of the biopesticides against stored grain insect pests [16], [30-32], but there are no references regarding the susceptibility of $T$. confusum to these biopesticides, to be compared with the results that were obtained in this study.

Literature presents several hypotheses regarding which factors may influence the efficacy of biopesticide residues in stored products and many of these hypotheses have not yet been fully tested due to the numerous variables involved. Some of the main factors that can influence the efficacy of biopesticides are bio-pathogens and dose [28,30,33], abiotic factors [34-37], as well as the product [10]. In our experiment, the lethal time parameter indicates that the biopesticides are as effective as the other isolates mentioned in the literature, especially the raw zeolite. The pathogenicity of the zeolite was the highest recorded among the three biopesticides, on no hull seeds. More specifically, T. confusum adults on no hull seeds had the lowest medial lethal time after exposure to zeolite, in comparison to the other tested biopesticides.

Although no data is available regarding the susceptibility of $T$. confusum to zeolite, Tribolium spp. individuals are the most tolerant among stored product insects [38-41]. Nevertheless, Vayias and Athanassiou [42] showed that T. confusum larvae were affected by diatomaceous earth dust and, therefore, even though adults are resilient, control can be achieved by exposing young larvae. Our study showed a significant high mortality percentage of $T$. confusum adults treated with the zeolite aqueous solution, in all tested doses.

Different strains of entomopathogenic fungi are known to differ in their pathogenicity-related characteristics [43-45], as confirmed by our results. B. bassiana and M. anisopliae both have a wide 
range of hosts [46]. Batta [14] reported that high mortality of Rhyzopertha dominica F. (Coleoptera: Bostrichidae) was obtained seven days after treatment with M. anisopliae. Wakefield et al. [47] reported 100\% mortality of Oryzaephilus surinamenis L. (Coleoptera: Silvanidae) and Ephestia kuehniella Zeller (Lepidoptera: Pyralidae) after 10 days of treatment with $10^{8}$ conidia/mL of B. bassiana. Hluchy and Samsinakova [48] noted that Boverosil ${ }^{\circledR}$ caused $90 \%$ mortality of O. surinamensis at $10^{8}$ conidia $/ \mathrm{mL}$.

Moino et al. [28] and Dal Bello et al. [49] reported that inoculation with Beauveria isolates produced a greater mortality of stored product pests than inoculation with Metarhizium isolates. Būda and Pečiulyte [50] found that all four fungal isolates of B. bassiana, L. lecanii, M. anisopliae var. anisopliae, and Isaria farinose were pathogenic to adults of the Indian meal moth [Plodia interpunctella Hübner (Lepidoptera: Pyralidae)]. Moreover, the treatment of stored wheat grains with formulated B. bassiana in milled rice significantly restricted the total grain weight loss that was caused by $S$. oryzae infestation and generated high rates of S. oryzae mortality [10]. On the contrary, Dal Bello et al. [51] reported that the treatment of S. oryzae with M. anisopliae was ineffective. Akbar et al. [13] concluded that B. bassiana, at a concentration of $10^{9}$ conidia/mL, had very little virulence against adults of $T$. castaneum.

In our study, all the fungal biopesticides were found to cause mortality to T. confusum. Lecan proved to be the most pathogenic to T. confusum on hull seeds, with higher sporulation percentage in cadavers and, in some cases, the shortest sporulation time. In fact, Lecan was the fastest in causing mortality and it also produced the highest number of cadavers that showed signs of infection after death. Moreover, the lowest median lethal time was recorded in the treatment with Lecan.

In all cases, the mortality of T. confusum adults was satisfactory. On the no hull seeds, the mortality that is caused by the zeolite was the highest among the three tested treatments. The fungal biopesticides also proved more pathogenic on the no hull than on the hull seeds. The type of seed can play role in the pathogenicity or effectiveness of the biopesticides. Generally, studies have shown that the presence of hull in the stored product confers some level of protection against infestation and facilitates post-harvest management $[52,53]$. Conversely, varieties with more cracks and splits in the hull provide a pathway for the entry of neonates [54,55]. This also supports our results that the level of mortality of stored product pests that is caused by biopesticides might also vary according to the type of seed.

\section{Conclusions}

For the protection of stored products, biopesticides, fungal or not, can be interchangeably used or together with other insecticides, to restrict the quantities of chemicals and to possibly lessen or delay the development of pest resistance. One advantage of pathogen-based control systems is the disease cycling. Upon death, the cadaver releases many infective agents, thus renewing the inoculum at the place where the insects had died. In this way, insect pests are exposed to lethal doses of the entomopathogen from the sporulating cadavers. Disease cycling can increase insecticidal effects in the long run, while zeolite formulations are effective in the short run. The use of these biopesticides could more effectively benefit the environment and protect stored grains.

Author Contributions: “Conceptualization, S.M.; methodology, S.M; software, S.M.; validation, S.M., P.A.E. and E.K.; formal analysis, S.M.; investigation, S.M., I.L., I.P. G.K., A.M., A.P. and M.T.; resources, S.M.; data curation, S.M. and P.A.E.; writing-original draft preparation, S.M.; writing-review and editing, S.M. and P.A.E.; visualization, S.M.; supervision, S.M.; project administration S.M.; funding acquisition".

Funding: This research received no external funding.

Acknowledgments: We would like to thank Ms. Ioanna Zampara, MA in Interpreting and Translating, for her help with the language.

Conflicts of Interest: The authors declare no conflict of interest.

\section{References}

1. Walsh, M.E.; dela Torre Ugarte, D.G.; Shapouri, H.; Slinsky, S.P. Bioenergy Crop Production in the United States: Potential Quantities, Land Use Changes, and Economic Impacts on the Agricultural Sector. Environ. Res. Econ. 2003, 24, 313-333. [CrossRef] 
2. Kerckhoffs, D.A.; Hornstra, G.; Mensink, R.P. Cholesterol-lowering effect of beta-glucan from oat bran in mildly hypercholesterolemic subjects may decrease when beta-glucan is incorporated into bread and cookies. Am. J. Clin. Nutr. 2003, 78, 221-227. [CrossRef] [PubMed]

3. Phillips, W.T.; Throne, E.J. Biorational approaches to managing stored-product insects. Annu. Rev. Entomol. 2010, 55, 375-397. [CrossRef] [PubMed]

4. Li, L.; Arbogast, R.T. The effect of grain breakage on fecundity, development, survival, and population increase in maize of Tribolium castaneum (Herbst) (Coleoptera: Tenebrionidae). J. Stored Prod. Res. 1991, 27, 87-94. [CrossRef]

5. Rice, W.C.; Cogburn, R.R. Activity of the entomopathogenic fungus Beauveria bassiana (Deuteromycota: Hyphomycetes) against three coleopteran pests of stored-grain. J. Econ. Entomol. 1999, 92, 691-694. [CrossRef]

6. Moore, D.; Lord, J.C.; Smith, S.M. Pathogens. In Alternatives to Pesticides in Stored-Product IPM; Subramanyam, B., Hagstrum, D.W., Eds.; Kluwer Academic Publishers: Dordreecht, The Netherlands, 2000; pp. 193-227.

7. Meikle, W.G.; Cherry, A.J.; Holst, N.; Hounna, B.; Markham, R.H. The effects of an entomopathogenic fungus, Beauveria bassiana (Balsamo) Vuillemin (Hyphomycetes), on Prostephanus truncatus (Horn) (Col.: Bostrichidae), Sitophilus zeamais Motschulsky (Col.:Curculionidae), and grain losses in stored maize in the Benin Republic. J. Invertebr. Pathol. 2001, 77, 198-205. [PubMed]

8. Lord, J.C. Desiccant dusts synergize the effect of Beauveria bassiana (Hyphomycetes: Moniliales) on stored-grain beetles. J. Econ. Entomol. 2001, 94, 367-372. [CrossRef] [PubMed]

9. Lord, J.C. Desiccation increases the efficacy of Beauveria bassiana for stored-grain pest insect control. J. Stored Prod. Res. 2007, 43, 535-539. [CrossRef]

10. Padin, S.; Dal-Bello, G.; Fabrizio, M. Grain loss caused by Tribolium castaneum, Sitophilus oryzae, and Acanthoscelides obtecus in stored durum wheat and beans treated with Beauveria bassiana. J. Stored Prod. Res. 2002, 38, 69-74. [CrossRef]

11. Stathers, T.; Zdarkova, E.; Wakefield, M.; Lukas, J.; Hubert, J. Entomopathogenic fungi in grain storage: Biological control of pest insects and mites with special reference to entomophathorales. In Biocontrol of Arthropod Pests in the Stored-Products, Proceedings of the Second Meeting of Working Group-4, Prague, Czech Republic, 30-31 May 2002; Zdarkova, E., Lukas, J., Hubert, J., Eds.; Research Institute of Crop Production: Prague, Czech Republic, 2002; pp. 100-109.

12. Wakefield, M.; Cox, P.D.; Wildey, K.B.; Price, N.R.; Moore, D.; Bell, B.A. The use of entomopathogenic fungi for stored product insect and mite control-further progress in the "Mycopest project". In Proceedings of the Second Meeting of WG4 of COST Action 842, Prague, Czech Republic, 8-14 September 2002; Zdarkova, E., Lukas, J., Hubert, J., Eds.; pp. 110-115.

13. Akbar, W.; Lord, J.C.; Nechols, J.R.; Howard, R.W. Diatomaceous earth increases the efficacy of Beauveria bassiana against Tribolium castaneum larvae and increases conidia attachment. J. Econ. Entomol. 2004, 97, 273-280. [CrossRef]

14. Batta, Y.A.; Abu Safieh, D.I. A study of treatment effect with Metarhizium anisopliae and four types of dusts on wheat grain infestation with red flour beetles (Tribolium castaneum Herbs, Coleoptera: Tenebrionidae). Islam. Univer. Gaza J. 2005, 13, 11-22.

15. Athanassiou, C.G.; Steenberg, T. Insecticidal effect of Beauveria bassiana (Balsamo) Vuillemin (Ascomycota: Hypocreaes) in combination with three diatomaceous earth formulations against Sitophilus granarius (L.) (Coleoptera: Curculionidae). Biol. Control. 2007, 40, 411-416. [CrossRef]

16. Batta, Y.A. Control of the rice weevil (Sitophilus oryzae L., Coleoptera: Curculionidae) with various formulations of Metarhizium anisopliae. Crop Prot. 2004, 23, 103-108. [CrossRef]

17. Kavallieratos, N.G.; Wakefield, M.E.; Athanassiou, C.G. Factors Affecting the Attachment of Conidia of Metarhizium Anisopliae (Metschnikoff) Sorokin (Deuteromycotina: Hyphomycetes) to Different Body Parts of Tribolium confusum Jacquelin du Val (Coleoptera: Tenebrionidae) Adults. IOBC/WPRS Bull 2008, 40, 181-190.

18. Zare, R.; Gams, W. A revision of Verticillium section Prostrata. IV. The genera Lecanicillium and Simplicillium. Nova Hedwig. 2001, 73, 1-50. 
19. Shinde, S.V.; Patel, K.G.; Purohit, M.S.; Pandya, J.R.; Sabalpara, A.N. Lecanicillium lecannii (ZIMM.) Zare and Gams" an important biocontrol agent for the management of insect pests-A review. Agric. Rev. 2010, 31, 235-252.

20. Andric, G.G.; Markovic, M.M.; Adamovic, M.; Dakovic, A.; Golic, M.P.; Kljajic, P.J. Insecticidal potential of natural zeolite and diatomaceous earth formulations against rice weevil (Coleoptera: Curculionidae) and red flour beetle (Coleoptera: Tenebrionidae). J. Econ. Entomol. 2012, 105, 670-678. [CrossRef]

21. Christidis, G.E.; Moraetis, D.; Keheyan, E.; Akhalbedashvili, L.; Kekelidze, N.; Gevorkyan, R.; Yeritsyan, H.; Sargsyan, H. Chemical and thermal modification of natural HEU-type zeolitic materials from Armenia, Georgia and Greece. Appl. Clay Sci. 2003, 24, 79-91. [CrossRef]

22. Breck, D.W. Zeolite Molecular Sieves: Structure, Chemistry and Use; Wiley: New York, NY, USA, 1974.

23. Abbott, W.S. A method for computing the effectiveness of an insecticide. J. Econ. Entomol. 1925, 18, $265-267$. [CrossRef]

24. IBM Corp. IBM SPSS Statistics for Windows; IBM Corp: Armonk, NY, USA, 2015; Available online: http://www-01.ibm.com/support/docview.wss?uid=swg21476197 (accessed on 8 March 2019).

25. Cox, D.R. Regression models and Life-tables. J. R. Stat. Soc. Ser. B (Methodol.) 1972, 34, 187-220. [CrossRef]

26. Fargues, J.; Goettel, M.S.; Smits, N.; Ouedraogo, A.; Vidal, C.; Lacy, L.A.; Lomer, C.J.; Rougier, M. Variability in susceptibility to simulated sunlight of conidia among isolates of entomopathogenic hyphomycetes. Mycopathologia 1996, 135, 171-181. [CrossRef] [PubMed]

27. Adane, K.; Moore, D.; Archer, S.A. Preliminary studies on the use of Beauveria bassiana to control Sitophilus zeamais (Coleoptera: Curculionidae) in the laboratory. J. Stored Prod. Res. 1996, 32, 105-113. [CrossRef]

28. Moino, A.; Alves, S.B.; Pereira, R.M. Efficacy of Beauveria bassiana (Balsamo) Vuillemin isolates for control of stored-grain pests. J. Appl. Entomol. 1998, 122, 301-305. [CrossRef]

29. Kassa, A.G.; Zimmermann, D.S.; Vidal, S. Susceptibility of Sitophilus zeamais (Motsch.) (Coleoptera: Curculionidae) and Prostephanus truncatus (Horn) (Coleoptera: Bostrichidae) to entomopathogenic fungi from Ethiopia. Biocontrol. Sci. Technol. 2002, 12, 727-736. [CrossRef]

30. Rodrigues, C.; Pratissoli, D. Patogenicidade de Beauveria brongniartii (Sacc) Petch. e Metarhizium anisopliae (Mots.) Sorok. e seu efeito sobre o gorgulho do milho e caruncho do feijaÄ o. An. Soc. Entomol. Bras. 1990, 19, 301-306.

31. Ekesi, S.; Egwurube, E.A.; AkpaI, A.D.; Onu, I. Laboratory evaluation of the entomopathogenic fungus, Metarhizium anisopliae for the control of the groundnut bruchid, Caryedon serratus on groundnut. J. Stored Prod. Res. 2001, 37, 313-321. [CrossRef]

32. Cherry, A.J.; Abalo, P.; Hell, K. A laboratory assessment of the potential of different strains of the entomopathogenic fungi Beauveria bassiana (Balsamo) Vuillemin and Metarhizium anisopliae (Metschnikoff) to control Callosobruchus maculatus (F.) (Coleoptera: Bruchidae) in stored cowpea. J. Stored Prod. Res. 2005, 41, 295-309. [CrossRef]

33. Hidalgo, E.; Moore, D.; Le Patourel, G. The effect of different formulations of Beauveria bassiana on Sitophilus zeamais in stored maize. J. Stored Prod. Res. 1998, 34, 171-179. [CrossRef]

34. Fargues, J.; Maniania, N.K.; Delmas, J.C.; Smits, N. Influence de la temperature sur la croissance in vitro d'hyphomycètes entomopathogènes. Agronomie 1992, 12, 557-564. [CrossRef]

35. Luz, C.; Fargues, J. Temperature and moisture requirements for conidial germination of an isolate of Beauveria bassiana, pathogenic to Rhodnius prolixus. Mycopathologia 1997, 138, 117-125. [CrossRef]

36. Luz, C.; Fargues, J. Effects of fluctuating moisture and temperature regimes on sporulation of Beauveria bassiana on cadavers of Rhodnius prolixus. Biocontrol. Sci. Technol. 1998, 8, 323-334.

37. Hallsworth, J.E.; Magan, N. Water and temperature relations of growth of the entomopathogenous fungi Beauveria bassiana, Metarhizium anisopliae, and Paecilomyces farinosus. J. Invertebr. Pathol. 1999, 74, 261-266. [CrossRef] [PubMed]

38. Korunic, Z. Diatomaceous earths, a group of natural insecticides. J. Stored Prod. Res. 1998, 34, 87-97. [CrossRef]

39. Fields, P.; Korunic, Z. The effect of grain moisture content and temperature on the efficacy of diatomaceous earths from different geographical locations against stored-product beetles. J. Stored Prod. Res. 2000, 36, 1-13. [CrossRef]

40. Athanassiou, C.G.; Kavallieratos, N.G. Insecticidal effect and adherence of PyriSecs in different grain commodities. Crop Prot. 2005, 24, 703-710. [CrossRef] 
41. Athanassiou, C.G.; Kavallieratos, N.G.; Vayias, B.J.; Tomanovic, Z.; Petrovic, A.; Rozman, V.; Adler, C.; Korunic, Z.; Milovanovic, D. Laboratory evaluation of diatomaceous earth deposits mined from several locations in central and southeastern Europe as potential protectants against coleopteran grain pests. Crop Prot. 2011, 30, 329-339. [CrossRef]

42. Vayias, B.J.; Athanassiou, C.G. Factors affecting the insecticidal efficacy of the diatomaceous earth formulation Silico-Sec against adults and larvae of the confused flour beetle, Tribolium confusum Du Val (Coleoptera: Tenebrionidae). Crop Prot. 2004, 23, 565-573. [CrossRef]

43. Zimmermann, G. Review on safety of the fungi Beauveria bassiana and Beauveria brongniartii. Biocontrol. Sci. Technol. 2007, 17, 553-596. [CrossRef]

44. Zimmermann, G. Review on safety of the fungus Metarhizium anisopliae. Biocontrol. Sci. Technol. 2007, 17, 879-920. [CrossRef]

45. Anderson, R.D.; Bell, A.S.; Blanford, S.; Paaijmans, K.P.; Thomas, M.B. Comparative growth kinetics and virulence of four different isolates of entomopathogenic fungi in the house fly (Musca domestica L.). J. Invertebr. Pathol. 2011, 107, 179-184. [CrossRef]

46. Humber, R.A.; Hansen, K.S. Hosts by Fungal Species. USDAĐARS Plant Protection Research Unit US Plant; Soil and Nutrition Laboratory: Ithaca, NY, USA, 2004.

47. Wakefield, M.E.; Cox, P.D.; Moore, D.; Aquino De Muro, M.; Bell, B.A. Mycopest: Results and perspectives. In Proceedings of the 6th Meeting of COST Action 842 Working Group IV Biocontrol of Arthropod Pests in Stored Products, Locorotondo, Italy, 10-11 June 2005; pp. 17-26.

48. Hluchy, M.; Samsinakova, A. Comparative study on the susceptibility of adult Sitophilus granarius (L.) (Coleoptera: Curculonoidae) and larval Galleria mellonella (L.) (Lepidoptera: Pyralidae) to the entomogenous fungus Beauveria bassiana (Bals.) Vuill. J. Stored Prod. Res. 1989, 25, 61-64. [CrossRef]

49. Dal Bello, G.; Padin, S.; Juarez, P.; Pedrini, N.B. Biocontrol of Acanthoscelides obtectus and Sitophilus oryzae with Diatomaceous Earth and Beauveria bassiana on stored grain. Biocontrol. Sci. Technol. 2006, 16, 215-220. [CrossRef]

50. Būda, V.; Pečiulytè, D. Pathogenicity of four fungal species to Indian meal moth Plodia interpunctella (Hübner) (Lepidoptera: Pyralidae). Ekologija 2008, 54, 265-270. [CrossRef]

51. Dal Bello, G.; Padin, S.; Lopez-Lastra, C.; Fabrizio, M. Laboratory evaluation of chemical-biological control of the rice weevil (Sitophilus oryzae L.) in stored grains. J. Stored Prod. Res. 2001, 37, 77-84. [CrossRef]

52. Cogburn, R.R. Domestic rice varieties: Apparent resistance to rice weevils, lesser grain borers and Angoumois grain moths. Environ. Entomol. 1974, 3, 681-685. [CrossRef]

53. Throne, J.E.; Baker, J.E.; Messina, F.J.; Kramer, K.J.; Howard, J.A. Varietal Resistance. In Alternatives to Pesticides in Stored-Product IPM; Subramanyam, B., Hagstrum, D.W., Eds.; Springer: Boston, MA, USA, 2000.

54. Chanbang, Y.; Arthur, F.H.; Wilde, G.E.; Throne, J.E. Control of Rhyzopertha dominica in stored rough rice through a combination of diatomaceous earth and varietal resistance. Insect Sci. 2008, 15, 455-460. [CrossRef]

55. Chanbang, Y.; Arthur, F.H.; Wilde, G.E.; Throne, J.E. Hull characteristics as related to susceptibility of different varieties of rough rice to Rhyzopertha dominica (F.) (Coleoptera: Bostrichidae). J. Stored Prod. Res. 2008, 44, 205-212. [CrossRef]

(C) 2019 by the authors. Licensee MDPI, Basel, Switzerland. This article is an open access article distributed under the terms and conditions of the Creative Commons Attribution (CC BY) license (http://creativecommons.org/licenses/by/4.0/). 